\title{
Pembangunan Sumber Daya Manusia Melalui Bidang Pendidikan Agama Kristen
}

\author{
Mardiharto \\ Sekolah Tinggi Teologi Baptis Indonesia Semarang \\ pastormardi@gmail.com
}

\begin{abstract}
ABSTRAK
Untuk membangun sebuah negara yang kuat maka masyarakatnya harus menjadi masyarakat yang terdidik, untuk itulah pemerintah melaksanakan salah satu program utamanya yaitu pembangunan sumber daya manusia. Sumer daya manusia perlu dibangun supaya masyarakatnya atau generasi penerus bangsa memiliki kemampuan secara kognitif, afektif dan psikomotor. Pendidikan Agama Kristen adalah salah satu bidang keilmuan yang diajarkan di sekoah-sekolah dan di perguran tinggi dengan dasar dari Firman Tuhan. Pendidikan Agama Kristen sebagai salah satu disiplin ilmu juga turut memberikan sumbangsih bagi negara dalam pembangunan sumber daya manusia.
\end{abstract}

Kata kunci: Pembangunan, sumber daya, pendidikan.

\section{PENDAHULUAN}

Pemerintah saat ini sedang gencargencarnya untuk menyuarakan salah satu programnya, yaitu pembangunan sumber daya manusia. Pembangunan sumber daya manusia bahkan menjadi prioritas utama dalam program pemerintah disamping program-program yang lainnya. Sumber daya manusia memegang peranan penting untuk menjadikan negara mengalami kemajuan, untuk itulah pembangunan sumber daya manusia menjadi program prioritas utama pemerintah. Untuk itu pemerintah dengan melakukan berbagai program yang mendukung peningkatan kualitas pendidikan, baik di tingkat dasar menengah maupun pendidikan tinggi dioptimalkan untuk mendorong daya saing bangsa. Untuk mendapatkan pendidikan yang berkualitas di Indonesia sebagian besar masih berpusat di pulau Jawa. Berdasarkan populasi penduduk baru 15,5 juta atau sekitar $8,5 \%$ dari total jumlah penduduk Indonesia yang mampu lulus dari perguruan tinggi dan sebanyak 26,3\% berpendidikan SMA, dan sisanya yaitu $65 \%$ hanya mengenyam pendidikan sampai di tingkat SMP $(22,8 \%)$ dan SD (42,4\%). ${ }^{1}$ Untuk itulah kwalitas sumber daya manusia dalam bidang pendidikan menjadi penentu dalam perubahan dan kemajuan untuk menjadi bangsa yang kuat dan maju dalam rangka bersaing dengan negara maju lainnya.

\section{METODE PENELITIAN}

Penelitian yang ada dalam jurnal ini adalah penelitian kualitatif, penulisan jurnal ini dengan menggunakan metode studi pustaka untuk mendapatkan data-data dan pembahasannya.

\section{PEMBAHASAN \\ Pengertian Pendidikan}

Dunia pendidikan formal haruslah mulai dibangun rata di seluruh wilayah negeri ini dengan memiliki kualitas yang sama, dalam

07/04/konsep-pembangunan-sdm-indonesia-jadibahasan-di-isic-2019/ 
rangka penyamarataan pendidikan. Sehingga untuk mendapatkan kualitas pendidikan tidak harus berpusat di Jawa. Hal ini akan dapat mempercepat pembangunan sumber daya manusia. Menurut Lawrene Gremin, pendidikan itu harus mencakup pengetahuan itu sendiri, sikap-sikap yang diperlukan, nilai-nilai, juga keahlian-keahlian, dan konsep pendidikan itu sendiri. Usaha dalam pendidikan harus dilakukan secara sengaja, sistematis, dan berkelanjutan untuk menyampaikan, menimbulkan, atau memperoleh capaian pendidikan itu. ${ }^{2}$

Menyoroti tentang pendidikan secara formal, seringkali manusia dalam mengikuti proses pendidikan, makna dan hakikat tentang pendidikan yang sebenarnya terlupakan. Hal ini terjadi karena manusia memandang bahwa pendidikan sebagai kewajiban yang harus ditempuh, bukan sebagai kebutuhan dan pada akhirnya kegiatan pendidikan menjadi rutinitas saja. Berdasarkan Undang-undang RI No. 20 Tahun 2003 tentang Sistem Pendidikan Nasional, tercantum pengertian pendidikan yang sebagai berikut;

"Pendidikan adalah usaha sadar dan terencana untuk mewujudkan suasana belajar dan proses pembelajaran agar peserta didik secara aktif mengembangkan potensi dirinya sehingga memiliki kekuatan spiritual keagamaan, pengendalian diri, kepribadian, kecerdasan, akhlak mulia, serta keterampilan yang diperlukan oleh dirinya, masyarakat, bangsa, dan negara". 3

Pendidikan merupakan usaha sadar yang diberikan dengan sengaja atau dilakukan dengan sadar oleh seseorang kepada orang lain (anak didik) agar orang lain itu mencapai kedewasaan secara susila menurut penuturan Hardi Budiyana. ${ }^{4}$ Menurut pahlawan pendidikan Ki Hadjar Dewantoro, pendidikan adalah sebagai daya upaya untuk memajukan perkembangan budi pekerti (kekuatan batin), pikiran

\footnotetext{
${ }^{2}$ Thomas H. Groome, Christian Religious

Education (Jakarta: BPK Gunung Mulia 2010), 29.

${ }^{3}$ UU RI No. 20 Tahun 2003 Tentang Sistem

Pendidikan Nasional, hal. 6

${ }^{4}$ Hardi Budiyana, Dasar-Dasar Pendidikan Agama

Kristen (Solo: Berita Hidup Seminary 2011), 2.
}

(intelek) dan jasmani anak-anak. Maksud dari pernyataan tersebut adalah supaya kita dapat memajukan kesempurnaan hidup, yaitu kehidupan dan penghidupan anak-anak, selaras dengan alamnya dan masyarakatnya. ${ }^{5}$

Untuk membangun sumber daya manusia yang lebih baik maka kita harus tahu bahwa pendidikan adalah upaya memanusiakan manusia, dan membudayakan manusia, sehingga mampu menciptakan, berkarya, berbudi baik bagi kehidupan ekosferisnya (kebulatan diri dan lingkungan). Dengan pembangunan sumber daya manusia melalui pendidikan yang merata maka negara sudah menganggap dan meningkatkann harkat dan martabat rakyatnya. Pemikiran seperti yang tersebut tadi harus ada pada semua lembaga pendidikan (pendidikan sekolah dan pendidikan luar sekolah), tidak terbatas pada jenjang tertentu dan jenis/bentuk kegiatan tertentu dalam rangka memposisikan manusia sebagai manusia, dan transformasi budaya, sehingga mampu menciptakan, berkarya, berbudi baik diri bagi kehidupan. Yang perlu dipahami pembangunan sumber daya manusia dalam bidang pendidikan adalah sebagai berikut; ${ }^{6}$

\section{Batas tentang Pendidikan}

Pendidikan mengandung banyak aspek dan sifatnya sangat kompleks. Karena sifatnya yang sangat kompleks itu, maka tidak sebuah batasan pun yang cukup memadai untuk menjelaskan arti pendidikan secara lengkap. Batasan tentang pendidikan yang dibuat oleh para ahli beraneka ragam, dan kandungannya berbeda yang satu dari yang lain. Perbedaan tersebut mungkin karena orientasinya, konsep dan dasar yang digunakan, aspek yang menjadi tekanan, atau karena falsafah yang melandasinya.

Di bawah ini dikemukakan beberapa batasan pendidikan yang berbeda berdasarkan fungsinya.

a. Pendidikan sebagai Proses Transformasi Budaya

\footnotetext{
${ }^{5}$ Nanang Purwanto, Pengantar Pendidikan (Yogyakarta: Graha Ilmu 2014), 23.

${ }^{6}$ Umar Tirtarahardja \& L. La Sulo, Pengantar

Pendidikan. (Jakarta: PT. Asdi Mahasatya, 2005), 33 - 36
} 
Sebagai proses transformasi budaya, pendidikan diartikan sebagai kegiatan pewarisan budaya dari satu generasi ke generasi yang lain. Proses pewarisan budaya tidak semata-mata mengekalkan budaya secara estafet. Pendidikan justru mempunyai tugas menyiapkan peserta didik untuk hari esok. Suatu masa dengan pendidikan yang menuntut banyak persyaratan baru yang tidak pernah diduga sebelumnya.

b. Pendidikan sebagai Proses

Pembentukan Pribadi

Sebagai proses pembentukan pribadi, pendidikan diartikan sebagai suatu kegiatan yang sistematis dan sistemik terarah kepada terbentuknya kepribadian peserta didik.

c. Pendidikan Sebagai Penyiapan Warga

Negara

Pendidikan sebagai penyiapan warga negara diartikan sebagai suatu kegiatan yang terencana untuk membekali peserta didik agar menjadi warga negara yang baik.

d. Pendidikan sebagai Penyiapan Tenaga

Kerja

Pendidikan sebagai penyiapan tenaga kerja diartikan sebagai kegiatan membimbing peserta didik sehingga memiliki bekal dasar untuk bekerja.

\section{Tujuan Pendidikan dan Pengajaran}

Tujuan pendidikan merupakan hal yang penting dalam proses pendidikan. Dengan adanya tujuan pendidikan maka segenap komponen-komponen dari seluruh kegiatan pendidikan dilakukan semata-mata terarah kepada atau ditujukan untuk mencapai tujuan tersebut. Maka menjadi keharusan bagi pendidikan untuk memahami akan tujuan dari pendidikan tersebut, kekurang pahaman pendidik terhadap tujuan pendidikan dapat mengakibatkan kesalahan di dalam melaksanakan pendidikan.

\section{Unsur-Unsur Pendidikan}

Dalam rangka pembangunan sumber daya manusia melalui bidang pendidikan untuk dapat mengalami perubahan dan kemajuan yang mampu bersaing dengan negara lain maka perlu sekali untuk dapat memahami unsur-unsur yang ada dalam pendidikan. Dari semua jenis pendidikan yang ada maka semuanya mengandung unsur-unsur sebagai berikut; ${ }^{7}$

1. Peserta didik. Peserta didik berstatus sebagai subyek didik karena ia pribadi yang otonom, yang ingin diakui keberadaannya, yang ingin mengembangkan diri secara terus menerus guna memecahkan masalah-masalah dalam kehidupannya.

2. Pendidik. Pendidik adalah orang yang bertanggung jawab terhadap pelaksanaan pendidikan dengan sasaran peserta didik. Peranan pendidik pada umumnya ditujukan untuk orang tua, guru, dan pelatih.

3. Interaktif edukatif. Interaktif edukatif adalah adanya interaksi/komunikasi secara timbal balik antara peserta didik dengan pendidik yang terarah kepada tujuan pendidikan.

4. Tujuan pendidikan. Tujuan pendidikan secara umum adalah tujuan dari keseluruhan jenis kegiatan selama berlangsungnya peristiwaperistiwa pendidikan.

5. Materi pendidikan. Materi pendidikan berperan sebagai sarana mencapai tujuan pendidikan. Materi pendidikan dibagi menjadi dua cakupan materi inti dan materi lokal. Materi inti bersifat nasional yang mengandung misi pengendalian dan persatuan bangsa. Materi lokal mempunyai misi mengembangkan kebinekaan kekayaan budaya sesuai dengan kondisi lingkungan.

6. Metode pendidikan. Dalam memilih dan menerapkan metode pendidikan, perlu memperhatikan kesesuaian dengan: (a) tujuan pendidikan; (b) peserta didik; (c) pendidik; (d) situasi dan kondisi lingkungan belajar.

7. Lingkungan pendidikan. Lingkungan pendidikan dibagi menjadi tiga tempat dan biasa disebut tri pusat pendidikan, yaitu keluarga, sekolah dan masyarakat.

\section{Pendidikan Agama Kristen}

Pendidikan Agama Kristen adalah salah satu bidang pendidikan yang diajarkan di sekolah - sekolah formal, dan pendidikan agama Kristen ini juga memberikan sumbangan dalam pembangunan sumber daya manusia dalam hal pembangunan karakter dan akhlak bagi peserta

\footnotetext{
${ }^{7}$ Nanang Purwanto, Pengantar Pendidikan

(Yogyakarta: Graha Ilmu, 2014), 25.
} 
didik yang masih duduk di bangku sekolah atau di perguruan tinggi. Pendidikan agama Kristen ini adalah bidang pendidikan yang memuat ajaran mengenai iman Kristen. Ajaran tentang iman Kristen yang dimaksudkan adalah ajaran-ajaran kekristenan dengan menekankan pada tiga aspek pendidikan yaitu pengetahuan (kognitif), sikap dan nilai-nilai (afektif), dan ketrampilan (psikomotor) yang berdasarkan kepada iman Kristen. E.G.

Homrighousen mengemukakan bahwa Pendidikan Agama Kristen adalah usaha sadar gereja dalam mendidik anak didiknya dalam rangka pewarisan iman Kristen dengan segala kebenaran, sebagaimana yang dinyatakan dalam Alkitab dan melatih mereka untuk hidup harmonis sesuai dengan iman Kristen, supaya mereka dapat menjadi anggota gereja yang dewasa yang menyadari imannya dan menyatakan dalam praktek kehidupan sehari-hari. ${ }^{8} \quad$ Sedangkan menurut Werner C. Graendorf, ia mengemukakan bahwa Pendidikan Agama Kristen adalah proses pengajaran dan pembelajaran yang berdasarkan pada Alkitab, berpusat pada Kristus, yang bergantung pada kuasa Roh Kudus, yang berusaha membimbing pribadi-pribadi pada semua tingkat pertumbuhan, melalui caracara pengajaran masa kini kearah pengenalan dan pengalaman tentang rencana dan kehendak Allah melalui Kristus di dalam setiap aspek hidup. ${ }^{9}$

Pendidikan Agama Kristen lebih ke arah wawasan pengetahuan, ajaran-ajaran yang berdasarkan kekristenan (Alkitab). Pendidikan juga harus mencapai sasaran aspek-aspek kognitif, afektif dan psikomotor. Dengan demikian dalam Pendidikan Agama Kristen melalui pengajaran harus mencapai sasaran aspek kognitif (pengetahuan), afektif (sikap dan nilai), dan psikomotor (ketrampilan). Lain halnya dengan Pendidikan Kristen lebih memberi warna pada suasana kehidupan kekristenan, pelaksanaan yang ada hubungannya dengan kekristenan. Jadi

${ }^{8}$ EG. Homrighausen, Pendidikan Agama Kristen (Jakarta: BPK Mulia, 1982), 31.
Pendidikan Kristen bukan hanya memberi pengajaran pengetahuan dan ketrampilan, Pendidikan Kristen juga memberi pengajaran dan kehidupan pada nilai-nilai kekristenan, nilai-nilai moral yang berdasar pada Firman Tuhan.

\section{KESIMPULAN}

Pendidikan Agama Kristen sebagai bagian dari keilmuan yang diajarkan di sekolah-sekolah dan perguruan tinggi juga ikut andil dalam pembangunan sumber daya manusia, seperti yang sedang dikerjakan oleh pemerintah. Melalui Pendidikan Agama Kristen diharapkan dapat mengubah peserta didik dari sisi kognitif, afektif dan psikomotornya, sehingga dengan demikian sungguh-sungguh mengalami perubahan demi sebuah kemajuan yang semakin berarti bagi pembangunan bangsa untuk menjadi negara yang maju dan memiliki daya saing yang tinggi dengan negara maju lainnya. Bidang Pendidikan Agama Kristen tidak sedang bersaing dengan ilmu-ilmu pengetahuan lainnya, tetapi pendidikan Agama Kristen memiliki tanggunng jawab moral untuk bisa dilihat hasil dari sisi kognitif, afektif dan psikomotormya. Sebagai suatu disiplin ilmu yang harus bisa merubah dari sisi sikap dan nilai.

\section{DAFTAR PUSTAKA}

Budiyana, Hardi, Dasar-Dasar Pendidikan Agama Kristen (Solo: Berita Hidup Seminary

2011)

Groome H Thomas., Christian Religious Education (Jakarta: BPK Gunung Mulia 2010)

Homrighausen, EG. Pendidikan Agama Kristen (Jakarta: BPK Mulia, 1982)

Purwanto, Nanang, Pengantar Pendidikan (Yogyakarta: Graha Ilmu 2014)

Tirtarahardja, Umar \& L. La Sulo, Pengantar Pendidikan. (Jakarta: PT. Asdi Mahasatya, 2005)

UU RI No. 20 Tahun 2003 Tentang Sistem Pendidikan Nasional

Umar Tirtarahardja \& L. La Sulo, Pengantar Pendidikan. (Jakarta: PT. Asdi Mahasatya,

\footnotetext{
${ }^{9}$ Graendorf, Werner C, Intrucduction to Biblikal Christian Education (Chaniago: Moody Press), 188.
} 
2005)

Graendorf, Werner C, Intrucduction to Biblikal Christian Education (Chaniago: Moody

Press).

http://sumberdaya.ristekdikti.go.id/index.p hp/2019/07/04/konseppembangunan-sdm-indonesia-jadibahasan-di-isic-2019/ 